\title{
Pengembangan Potensi SDM Pesantren Melalui Pelatihan Pemahaman dan Pengetahuan Pengelolaan Keuangan
}

\author{
Etty Gurendrawati ${ }^{1}$, Yunika Murdayanti ${ }^{2}$ dan Susi Indriani $^{3}$ \\ 1,2,3 Fakultas Ekonomi, Universitas Negeri Jakarta \\ Email: egurendra@unj.ac.id ${ }^{1}$, yunika_murdayanti@unj.ac.id ${ }^{2}$, \\ sisusie,indriani@gmail.com ${ }^{3}$
}

\begin{abstract}
ABSTRAK
Kegiatan pengabdian masyarakat ini dilakukan karena masih ditemukan beberapa kelemahan dari pengelolaan pondok pesantren. Umumnya masalah tersebut bermula dari aktivitas keuangan pesantren baik yang berkaitan dengan anggaran, akuntansi, penataan administrasi, alokasi serta kebutuhan pengembangan pesantren maupun dalam proses aktivitas keseharian pesantren. Tidak sedikit pesantren yang memiliki sumber daya baik manusia maupun alamnya tidak tertata dengan rapi, dan tidak sedikit pula proses pendidikan pesantren berjalan lambat karena kesalahan dalam penataan manajemen keuangannya. Pelaksanaan Pengabdian Masyarakat ini dilakukan di di pondok pesantren Qotrun Nada Depok Jawa Barat. Peserta diberikan pelatihan pemahaman dan pengetahuan pengelolaan keuangan secara komputerisasi dan pembuatan laporan keuangan yang baik serta kiatkiat dalam mengelola pengendalian biaya yang rutin dikeluarkan baik yang terjadi pada saat usaha maupun pengeluaran rumah tangga pesantren sehingga mampu mengatasi pengeluaran yang besar. Kesimpulan yang diperoleh terdapat peningkatan pemahaman dan pengetahuan pengelolaan keuangan serta teknik dalam membuat bentuk laporan keuangan yang baik dan benar baik secara manual maupun terkomputerisasi.
\end{abstract}

Kata Kunci: komputer akuntansi; laporan keuangan; pengetahuan keuangan.

\section{ABSTRACT}

This community development activity was carried out because there were still some weaknesses in the management of pesantren. Generally, the problem starts from the pesantren's financial activities both related to the budget, accounting, administration managements, allocation and development needs of the pesantren and even in the process of pesantren's daily activities. Many pesantren with its resources both human and natural are not neatly arranged, and also the process of pesantren education runs slowly due to errors in financial management arrangements. The implementation of community develompent is done at the Pesantren Qotrun Nada in Depok, West Java. Participants are given training in understanding and knowledge of financial management manually and also accounting computerized application. Participants are also given a training materials of good financial report preparation and tips on managing routine cost control. The conclusions obtained are an increase in understanding and knowledge of financial management for all participants and also understand the techniques in making good financial statements both manually and computerized.

Keywords: accounting computerized; financial literacy; financial statements.

PENDAHULUAN

Pesantren dikenal sebagai model pendidikan yang multi aspek dalam pola pembelajaran terhadap para santrinya. Dalam perjalanannya telah terbukti model pendidikan ini mampu 
mempertahankan keberlangsungan dirinya (survival system). Santri tidak hanya dididik menjadi seseorang yang mengerti ilmu agama, tetapi juga mendapat tempaan kepemimpinan yang alami, kemandirian, kesederhanaan, ketekunan, kebersamaan, kesetaraan, dan sikap positif lainnya. Modal inilah yang diharapkan melahirkan masyarakat yang berkualitas dan mandiri sebagai bentuk partisipasi pesantren dalam menyukseskan tujuan pembangunan nasional sekaligus berperan aktif dalam mencerdaskan bangsa sesuai yang diamanatkan oleh Undangundang Dasar 1945 (Usman, 2013).

Beberapa penelitian mengemukakan seperti Subkhan (2012) menjelaskan bahwa peran kyai dalam evaluasi dan pertanggungjawaban terhadap pembiayaan lebih ditekankan pada perananya sebagai pengaudit atau supervisor keuangan. Arifin dan Raharjo (2014) menganalisis laporan keuangan pondok pesantren hanya menyajikan laporan penerimaan kas dan pengeluaran kas, yang tidak sesuai dengan pos-pos pengklasifikasian yang sesuai dengan standar akuntansi keuangan yang berlaku disebabkan karena yayasan tidak mengenal standar akuntansi yang digunakan sebagai pedoman pelaporan keuangan bagi entitas nirlaba.

Pengelolaan keuangan sangat penting dalam setiap perusahaan, karena dengan pengelolaan keuangan yang baik dapat memperlancar aktivitas perusahaan. Menurut Fitri (2014) pengelolaan keuangan meliputi: kegiatan perencanaan, penggunaan atau pemanfaatan, pencatatan data, pelaporan dan pertanggungjawaban yang dialokasikan untuk menyelenggarakan sekolah dengan tujuan untuk menunjukkan tertib adminstrasi keuangan sehingga pengurusannya dapat dipertanggungjawabkan sesuai dengan ketentuan yang berlaku.

Penggunaan anggaran dan keuangan, dari sumber manapun, baik pemerintah ataupun dari masyarakat perlu didasarkan pada prinsip-prinsip umum pengelolaan pengelolaan keuangan sebagai berikut (Masyhud, 2003):

1. Hemat, tidak mewah, efisien dan sesuai dengan kebutuhan teknis yang disyaratkan.

2. Terarah dan terkendali sesuai dengan rencana, program / kegiatan.

3. Terbuka dan transparan, dalam pengertian dari dan untuk apa keuangan lembaga tersebut perlu dicatat dan dipertanggungjawabkan serta disertai bukti penggunaannya.

4. Sedapat mungkin menggunakan kemampuan/hasil produksi dalam negeri sejauh dimungkinkan.

Pihak pesantren bersama komite atau majelis pesantren pada setiap awal tahun anggaran perlu bersama-sama merumuskan rencana anggaran pendapatan dan belanja pondok pesantren (RAPBPP) sebagai acuan bagi pengelola pesantren dalam melaksanakan, manajemen keuangan yang baik. 
Etty Gurendrawati ${ }^{1}$, Yunika Murdayanti ${ }^{2}$ dan Susi Indriani ${ }^{3}$ /Aksiologiya: Jurnal Pengabdian Kepada Masyarakat. Vol.4, No.1, Februari 2020 Hal 20 - 36

Anggaran sendiri merupakan rencana yang diformulasikan dalam bentuk rupiah dalam jangka waktu atau periode tertentu, serta alokasi sumber-sumber kepada setiap bagian kegiatan. Anggaran memiliki peran penting di dalam perencanaan, pengendalian dan evaluasi kegiatan yang dilakukan pondok pesantren. Untuk itu setiap penanggung jawab program kegiatan di pesantren harus menjalankan kegiatan sesuai dengan anggaran yang telah ditentukan sebelumnya.

Ada dua bagian pokok anggaran yang harus diperhatikan dalam penyusunan RAPBPP, yaitu: Rencana sumber atau target penerimaan/ pendapatan dalam satu tahun yang bersangkutan, termasuk di dalamnya sumber-sumber keuangan dari:

1. Kontribusi santri

2. Sumbangan dari individu atau organisasi

3. Sumbangan dari pemerintah (Bila Ada)

4. Dari hasil usaha pesantren

Semua pengeluaran keuangan Pondok Pesantren dari sumber manapun harus dipertanggungjawabkan. Pertanggung jawaban tersebut menjadi bentuk dari transparasi pengelolaan keuangan. Pada prinsipnya pertanggung jawaban tersebut dilakukan dengan mengikuti aturan dari sumber anggaran. Namun demikian prinsip transpari dan kejujuran dalam pertanggung jawaban keuangan pondok pesantren harus tetap dijunjung tinggi. Dalam kaitan dengan pengelolaan keuangan tersebut, yang perlu diperhatikan oleh bendaharawan pondok pesantren adalah sebagai berikut.

1. Pada setiap akhir tahun anggaran, bendaharawan harus membuat laporan keuangan kepada komite/majelis pesantren untuk dicocokkan dengan RAPBPP.

2. Laporan keuangan tersebut harus dilampiri bukti-bukti laporan yang ada, termasuk bukti penyetoran pajak (PPN \& PPh) bila ada.

3. Kuitansi atau bukti-bukti pembelian atau bukti penerimaan berupa tanda tangan, penerimaan honorarium/bantuan/bukti pengeluaran lain yang sah.

4. Neraca keuangan juga harus ditunjukkan untuk diperiksa oleh pertanggung jawaban keuangan dari komite pondok pesantren

Terlepas dari prospek masa depan pesantren, ada beberapa masalah yang dihadapi pesantren disebabkan keterbatasan kemampuan pengelolanya. Masalah tersebut antara lain (Usman, 2013):

1. Sarana dan prasarana penunjang yang terlihat masih kurang memadai. Selama ini, kehidupan pondok pesantren yang penuh kesederhanaan dan kebersahajaannya tampak masih memerlukan tingkat penyadaran dalam melaksanakan pola hidup yang bersih dan sehat yang didorong oleh penataan dan penyediaan sarana dan prasarana yang layak dan memadai. 
2. Sumber daya manusia. Sekalipun sumber daya manusia dalam bidang keagamaan tidak dapat diragukan lagi, tetapi dalam rangka meningkatkan eksistensi dan peranan pondok pesantren dalam bidang kehidupan sosial masyarakat, diperlukan perhatian yang serius. Penyediaan dan peningkatan sumber daya manusia dalam bidang manajemen kelembagaan, serta bidang-bidang yang berkaitan dengan kehidupan social masyarakat, harus menjadi prioritas pesantren.

3. Manajemen kelembagaan. Manajemen merupakan unsur penting dalam pengelolaan pesantren. Pada saat ini masih terlihat bahwa pesantren dikelola secara tradisional apalagi dalam penguasaan informasi dan teknologi yang masih belum optimal. Hal tersebut dapat dilihat dalam proses pendokumentasian (data base) santri dan alumni pesantren yang masih kurang terstruktur.

4. Kemandirian ekonomi kelembagaan. Kebutuhan keuangan selalu menjadi kendala dalam melakukan aktivitas pesantren, baik yang berkaitan dengan kebutuhan pengembangan pesantren maupun dalam proses aktivitas keseharian pesantren. Tidak sedikit proses pembangunan pesantren berjalan dalam waktu lama yang hanya menunggu sumbangan atau donasi dari pihak luar, bahkan harus melakukan penggalangan dana di pinggir jalan.

5. Kurikulum yang berorientasi life skills santri dan masyarakat. Pesantren masih berkonsentrasi pada peningkatan wawasan dan pengalaman keagamaan santri dan masyarakat. Apabila melihat tantangan kedepan yang semakin berat, peningkatan kapasitas santri dan masyarakat tidak hanya cukup dalam bidang keagamaan semata, tetapi harus ditunjang oleh kemampuan yang bersifat keahlian.

Tujuan dari kegiatan ini adalah sebagai berikut.

1. Memberikan perlindungan kepada pada pesantren agar tidak terjerat dengan pengeluaran yang banyak serta kiat-kiat dalam memperoleh dana dari pihak luar.

2. Mewujudkan kemandirian dengan menggunakan modal pesantren serta mampu memenuhi segala tuntutan operasionalnya.

3. Mampu membuat perencanaan keuangan baik jangka pendek maupun jangka panjang serta keunggulan kompetitif guna mencapai kesejahteraan dan peningkatan taraf hidup lingkungan pesantren.

4. Mampu melakukan manajemen keuangan sederhana dalam mengelola operasional kostnya, yaitu mampu menghitung pendapatannya serta membandingkan biaya listrik, air dan biaya lainnya. 
5. Mampu membuat pertanggungjawaban keuangan sesuai dengan prosedur keuangan yang berlaku.

6. Mampu membuat pencatatan keuangan yang terdiri dari penerimaan kas dan pengeluaran kas baik secara manual maupun terkomputerisasi.

7. Mampu membuat laporan keuangan yang bisa disajikan setiap tahunnya.

Masalah pada pengabdian masyarakat ini difokuskan pada Pondok Pesantren Qotrun Nada. Berikut ini akan dijelaskan secara singkat profil pondok pesantren tersebut.

Pondok pesantren Qotrun Nada didirikan pada tahun 1996 di tengah keinginan sesepuh, ulama, Asatidz dan masyarakat Desa Cipayung Jaya untuk mengawali proses perubahan sosial dan budaya masyarakat yang berkembang begitu pesatnya. Melalui visi "AlMuhaafadzatu 'Alal Qodiimisshoolih Wal Akhzu Biljadiidil Ashlah", yang berartikan "Melestarikan nilai-nilai klasik yang baik dan mengambil nilai-nilai baru yang lebih baik". Pondok Pesantren Qotrun Nada berniat menjadi benteng perubahan dan perkembangan yang sampai saat ini terus berpacu dengan waktu demi mewujudkan visinya dan berperan sebagai lembaga pendidikan yang menyiapkan dan mencetak kader ummat yang berakhlakul karimah, berilmu amaliyah dan beramal ilmiah.

Di dalam menjalankan aktifitas pendidikan dan pengajarannya terangkum misi menciptakan generasi yang berakhlakul karimah, berilmu intelektual dan selalu mengerjakan perintah-Nya dan menjauhi semua larangan-Nya. Pondok Pesantren Qotrun Nada berusaha mengkolaborasikan antara dua latar belakang sistem pendidikan, yaitu antara sistem pendidikan pondok pesantren modern dengan sistem pendidikan pesantren salafiyah, sehingga jadilah Qotrun Nada sebagai sebuah lembaga yang menggunakan "Bilingual System of Education". Proses pendidikan dan pengajaran di Pondok Pesantren Qotrun Nada dilaksanakan secara aktif, kreatif, dan penuh dedikasi yang tinggi serta oleh keikhlasan para pendidik dan pengajar yang sangat berkompeten dalam bidangnya masing-masing, yakni sebanyak 130 orang. Pondok Pesantren Qotrun Nada terus berkembang hingga memiliki 1500 orang santri, yang didalamnya juga terdapat anak-anak yatim, piatu dan dhua'fa yang menjadi tanggung jawab Qotrun Nada sebagai salah satu peran sosial kemasyarakatnya. 

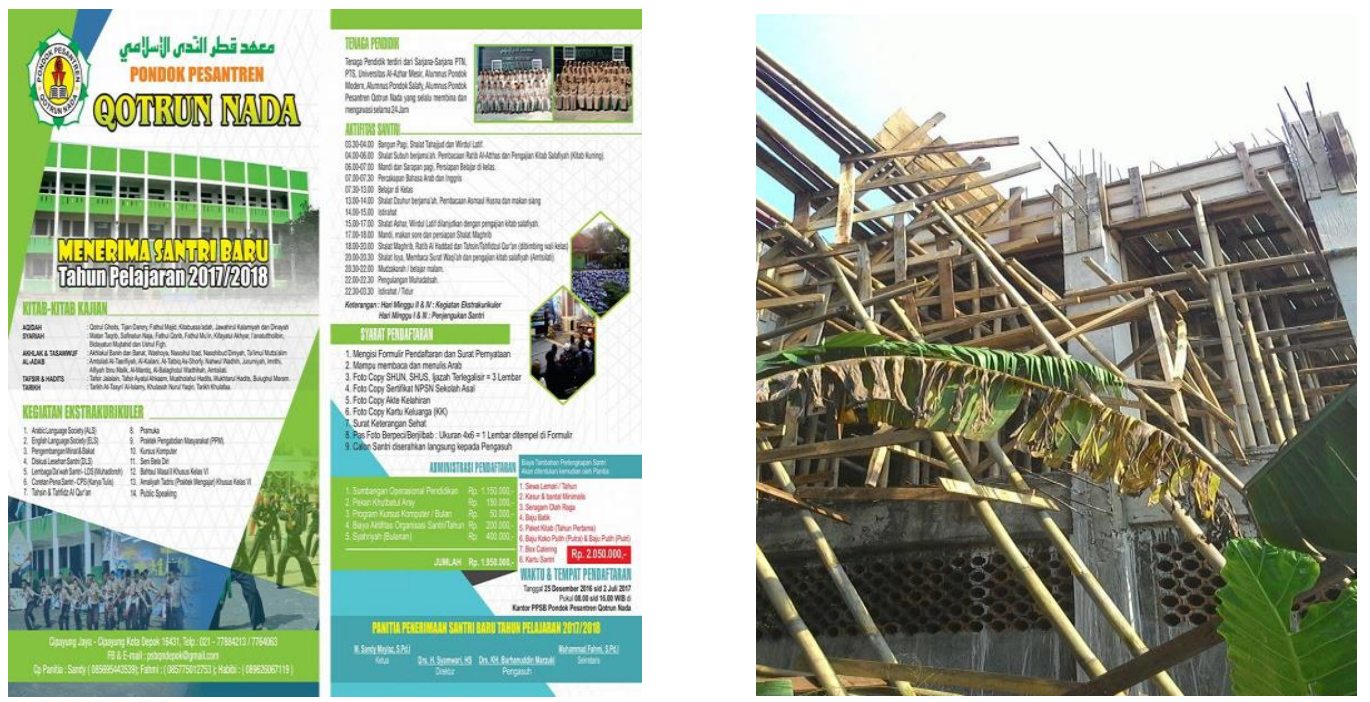

Gambar 1. Biaya Pendaftaran dan Pembangunan Gedung Pesantren Qotrun Nada

Dalam pola pendidikan pondok pesantren dapat dilihat peranan ketokohan yang sangat kuat di mana peran Kyai sangat besar dalam semua aspek sampai ke keuangan. Berdasar data awal yang telah digali dari dua pondok pesantren ini didapati bahwa dalam perencanaan pembiayaan pendidikan, penentu sumber pendanaan (donator utama) serta pengelolaan dana pendidikan serta pengembangan pondok menjadi tugas dan tanggung jawab Kyai. Peran kyai dalam pengelolaan pembiayan dan penggunaan dana bertindak sebagai manajer dan pengasuh sekaligus panutan bagi santri, maka ketokohan para Kyai ini akan menjadi pusat pengembangan pondok pesantren yang dipimpinnya. Secara tekhnis pelaksanaannya akan dibantu oleh pengurus yayasan yang bertugas mencari dana tambahan untuk yayasan dari para pihak masyarakat yang menjadi donator. Setelah mendapatkan dana, keputusan pengurus yayasan berikutnya adalah mengalokasikan dana tersebut kepada para santri untuk berbagai keperluan, seperti: untuk kebutuhan biaya sekolah, uang saku harian, untuk kebutuhan makan harian, membayar listrik, telpon, membayar tenaga untuk memasak dan membersihkan kantor yayasan, serta kebutuhankebutuahn lainnya yang berhubungan dengan yayasan. Sumber dana pondok yang dikelola akan menjadi aset atau harta bagi pondok pesantren yang umumnya berbentuk yayasan. Tentunya pengadministrasian dan pengelolaan keuangan membutuhkan suatu pencatatan, penyajian dan pelaporan keuangan yang transparan dan terstandar. Harapannya adalah output pelaporan keuangan pondok pesantren dapat dijadikan acuan bagi pengguna internal pesantren itu sendiri ataupun pihak eksternal yaitu donatur dan masyarakat pada umumnya sesuai dengan kebutuhan tiap penggunanya. 
Berdasarkan analisis situasi diatas yang berlandaskan hasil kuesioner dan wawancara dari penelitan terdahulu, disebutkan dibawah ini hasil permasalahan dari mitra yaitu sebagai berikut.

1. Pengelolaan dari perencanaan keuangan pesantren dalam menjalankan aktifitas operasionalnya masih terkendalam sumber daya manusia yang terbatas.

2. Kurangnya pemahaman pesantren dalam pengaturan pengeluaran rutin, pembayaran, belanja kebutuhan atau barang serta pengeluaran lainnya agar tidak mengalami lebih besar pasak daripada tiang.

3. Tidak terdapat prosedur keuangan yang baik di pesantren dan tidak tertulis.

4. Pencatatan keuangan baik untuk penerimaan kas dan pengeluaran kas yang dilakukan oleh pesantren masih dilakukan secara manual dan sesuai dengan kebutuhan saja.

5. Pertanggungjawaban keuangan hanya kepada pimpinan pondok pesantren.

\section{METODE}

Kerangka atau tahapan kegiatan Pengembangan Potensi SDM Pesantren melalui Pelatihan Pemahaman dan Pengetahuan Pengelolaan Keuangan adalah:

\section{Analisis Kebutuhan}

Berdasarkan diskusi yang dilakukan oleh tim pelaksana pengabdian masyarakat memerlukan program pelatihan ini karena:

a. Kurangnya pemahaman dalam pengelolaan biaya yang mengakibatkan beberapa pelaporan keuangan menghasilkan transaksi minus sehingga tidak dapat menghasilkan suatu struktur modal keuangan yang baik.

b. Kurangnya pemahaman cara cerdas mengatur pembelanjaan, pembayaran, dan pengeluaran lainnya agar tidak mengalami lebih besar pasak daripada tiang

c. Kurangnya pemahaman dalam melakukan perencanaan keuangan yang mempunyai kecerdasan dalam mengelola keuangan.

d. Pesantren pada umumnya sudah membuat sistem anggaran yang baik hanya saja masih minim pengetahuan keuangan sehingga pengelolaan keuangannya belum sesuai dengan standar akuntansi yang berlaku.

e. Sumber daya manusia yang masih minim pengetahuannya dalam bidang akuntansi keuangan sehingga sulit untuk melakukan pencatatan keuangan sesuai standar akuntansi yang berlaku, hal tersebut juga didukung oleh karyawan yang tidak semuanya berasal dari lulusan akuntansi.

Berdasarkan permasalahan diatas, maka secara singkat, pemecahan masalah dapat dilihat pada diagram dibawah: 


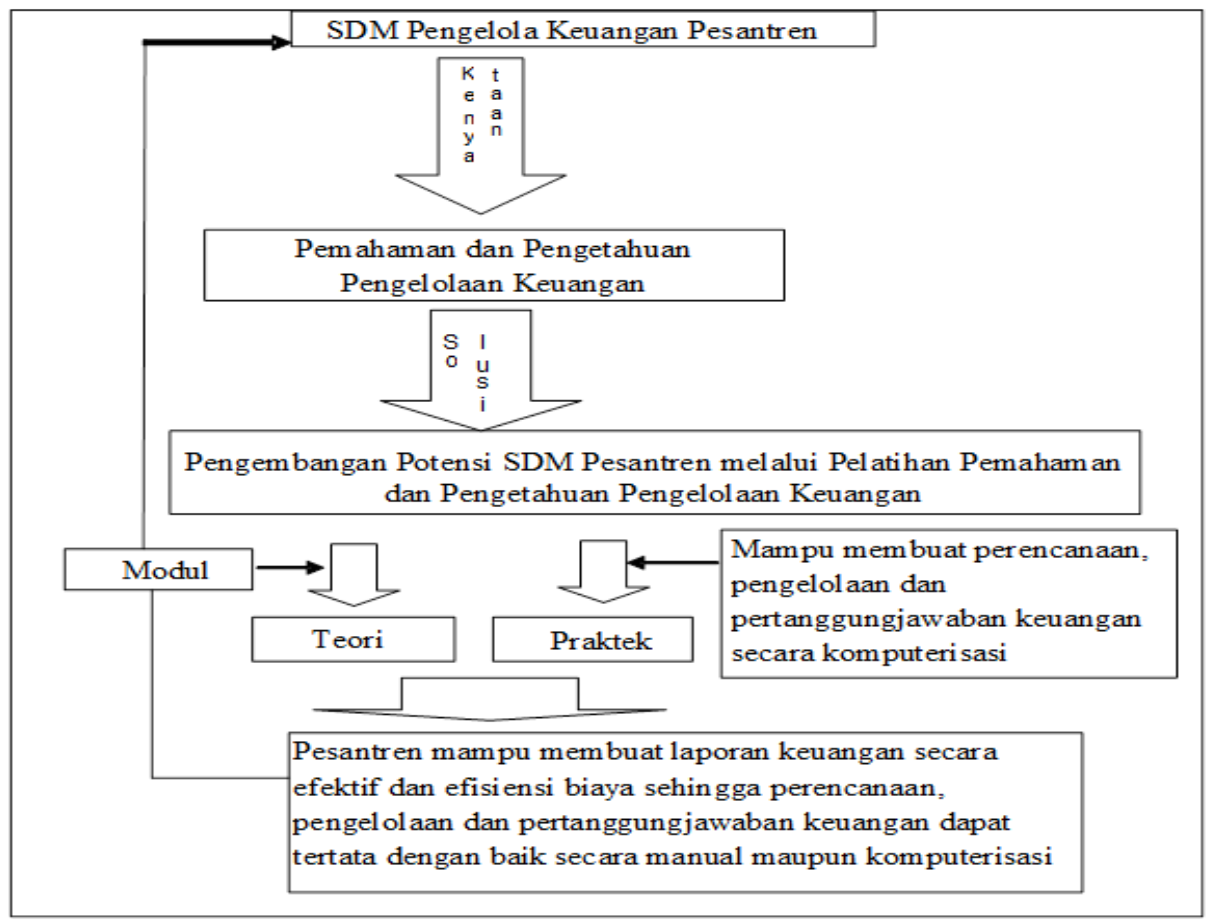

Gambar 2. Kerangka Pemecahan Masalah

\section{Rancangan Instruksional}

Dalam menentukan rancangan instruksional ini perlu dipertimbangkan aspek-aspek berikut:

a. Isi materi program pelatihan yang relevan dengan kebutuhan peserta. Tim pelaksanaan telah menetapkan kebutuhan materi bagi para SDM pengelola keuangan di pesantren yaitu pengetahuan pengurus atau pengelola pesantren tentang perkembangan pengelolaan keuangan yang terstandarisasi.

b. Modul praktik diperoleh dari nara sumber mengenai materi Pelatihan tentang Tips dan Trik memahami Pengelolaan Keuangan Pesantren dan Panduan Praktis mengenal akuntansi jasa berupa penguasaan praktek akuntansi dengan aplikasi komputer akuntansi Excell.

c. Mendemonstrasikan penggunaan software aplikasi komputer akuntansi Excell dalam kegiatan keuangan pesantren

\section{Tahap Pengembangan}

Tim pelaksana pengabdian masyarakat berupaya mengembangkan pelatihan ini baik dalam hal materi pelatihan, modul, dan tanya jawab dalam bentuk yang relevan dengan aspek pengelolaan keuangan dalam Pengembangan Potensi SDM Pesantren melalui Pelatihan Pemahaman dan Pengetahuan Pengelolaan Keuangan.

1. Kegiatan observasi dilakukan secara langsung oleh tim pelaksana melalui questioner atas pelaksanaan pengabdian 
Etty Gurendrawati ${ }^{1}$, Yunika Murdayanti ${ }^{2}$ dan Susi Indriani ${ }^{3}$ /Aksiologiya: Jurnal Pengabdian Kepada Masyarakat. Vol.4, No.1, Februari 2020 Hal 20 - 36

masyarakat yang dilakukan sebelum dan sesudah proses di lapangan selesai. Observasi berupa pemahaman peserta (SDM Pengelola Keuangan) terhadap pengelolaan keuangan yang baik dan pemanfaatan aplikasi komputer akuntansi Excell dalam operasional pesantren.

2. Wawancara dengan pimpinan pondok pesantren yang bersedia untuk dibantu pengelolaan keuangannya untuk menjadi lebih efektif dan efisien.

3. Ceramah dan tatap muka mengenai pengenalan akuntansi melalui standar akuntansi keuangan khusus organisasi nir laba dan manfaatnya.

Teknik analisis data dalam kegiatan ini dilakukan untuk mengetahui tingkat penguasaan materi pelatihan oleh para pengurus keuangan pesantren, pelaksanaan kegiatan dan dampak kegiatan. Adapun indikator yang digunakan dalam analisis data adalah:

1. Peningkatan pengelolaan keuangannya sendiri sehingga dapat menghasilkan suatu struktur modal keuangan yang baik.

2. Peningkatan kemampuan keterampilan akuntansi

3. Peningkatkan keahlian menggunakan komputer serta mampu mengaplikasin pencatatan keuangannya secara komputerisasi.
4. Pengelolaan sumber daya baik di dalam dirinya sendiri maupun diluar dirinya untuk menghasilkan kemandirian ekonomi pesantren.

5. Peningkatan keuletan dan ketelitian dalam melakukan pencatatan keuangan.

6. Peningkatan kreatifitas

Data-data diatas diperoleh dengan menggunakan teknik analisis kualitatif deskriptif. Data-data dikumpulkan dan dikategorikan berdasarkan hasil kuesioner dan wawancara yang dilakukan kemudian dideskripsikan secara naratif.

Kegiatan pengabdian masyarakat ini akan dilakukan Pesantren Qotrun Nada di Jalan Qotrun Nada No. 1, Cipayung Jaya, Cipayung, Kota Depok, Jawa Barat. Anggota khalayak yang dianggap strategis untuk dilibatkan adalah Para SDM Pengelola Keuangan di Pesantren Qotrun Nada di Jalan Qotrun Nada No. 1, Cipayung Jaya, Cipayung, Kota Depok, Jawa Barat. Waktu pelaksanaan kegiatan pengabdian masyarakat ini dengan tema Pengembangan Potensi SDM Pesantren Melalui Pelatihan Pemahaman Dan Pengetahuan Pengelolaan Keuangan yaitu pada tanggal 12 Agustus 2018 Kegiatan pengabdian masyarakat ini dilaksanakan selama 6 bulan yaitu Mei-Oktober 2018.

\section{PEMBAHASAN}


Etty Gurendrawati', Yunika Murdayanti ${ }^{2}$ dan Susi Indriani ${ }^{3}$ /Aksiologiya: Jurnal Pengabdian Kepada Masyarakat. Vol.4, No.1, Februari 2020 Hal 20 - 36

Deskripsi Kegiatan

Kegiatan

pelatihan

Pengembangan Potensi SDM

Pesantren Melalui Pelatihan

Pemahaman dan Pengetahuan

Pengelolaan Keuangan dilaksanakan

di Pondok Pesantren Qotrun Nada pada hari Minggu tanggal 12 Agustus 2018 pukul 08.00 - 15.00. Pelatihan ini diisi oleh 2 orang narasumber dan dibantu oleh tim panitia.

Pelatihan ini diikuti 15 orang peserta yang merupakan Para SDM Pengelola Keuangan di Pesantren Qotrun Nada di Jalan Qotrun Nada No. 1, Cipayung Jaya, Cipayung, Kota Depok, Jawa Barat. Waktu pelaksanaan kegiatan pengabdian masyarakat ini dengan tema Pengembangan Potensi SDM Pesantren Melalui Pelatihan Pemahaman Dan Pengetahuan Pengelolaan Keuangan yaitu pada tanggal 12 Agustus 2018 Kegiatan pengabdian masyarakat ini dilaksanakan selama 6 bulan yaitu Mei-Oktober 2018.

Penekanan pelatihan ini terletak ada sejauh mana bertambahnya pemahaman dan kemampuan peserta dalam hal pengelolaan keuangan. Yaitu bagaimana peserta menjadi mengetahui apa yang dimaksud dengan pengelolaan keuangan pesantren, pengenalan akuntansi pesantren yang dikeluarkan oleh Ikatan Akuntan Indonesia dan Bank Indonesia, tata cara membuat pencatatan sederhana untuk mencatatat pendapatan maupun pengeluarannya, belajar membuat suatu akun transaksi dan kemudian mampu membuat pencatatan pengelolaan keuangan yang baik dan benar dengan menggunakan aplikasi komputer akuntansi khusus pesantren.

Sesi pertama pelatihan disampaikan materi mengenai pengelolaan keuangan pesantren berdasarkan pedoman akuntansi pesantren yang diterbitkan oleh Ikatan Akuntan Indonesia dan Bank Indonesia. Materi dimulai dengan penyampaian mengenai apa yang dimaksud dengan akuntansi pesantren, manfaat akuntansi pesantren, aplikasi pesantren dengan berlandaskan Pedoman Akuntansi Pesantren dari Bank Indonesia dan Ikatan Akuntan Indonesia pada Mei 2018 yang menjelaskan bahwa pedoman akuntansi ini mengacu pada Standar Akuntansi Keuangan Entitas Tanpa Akuntabilitas Publik (SAK ETAP) yang sudah dikeluarkan DSAK IAI, serta dilanjutkan mengenai transaksi-transaksi penerimaan dan pengeluaran rutin yang terdapat di operasional pesantren berikut penyajiannya di dalam laporan keuangan. Peserta diajarkan untuk bisa mengidentifikasi pengeluaran-pengeluaran yang ada sekaligus diberi pemahaman mengenai bagaimana menghemat pengeluaran atau menambah penghasilan. Peserta juga diberikan materi mengenai alokasi yang harus dilakukan atas pendapatan yang diterima. Peserta pengelola keuangan di pesantren juga diajak berdiskusi untuk mampu untuk mengatasi 
piutang yang banyak terjadi pada iuran santri.

Pada sesi kedua materi yang disampaikan adalah mengenai aplikasi keuangan dengan bantuan program komputer ms excell. Peserta dilatih untuk menggunakan aplikasi keuangan yang telah disediakan oleh panitia, untuk itu peserta diminta untuk membawa laptop, sehingga masing-masing peserta dapat mempraktikan aplikasi tersebut secara mandiri. Aplikasi tersebut memungkinkan peserta pengelola laporan keuangan di pesantren mampu membuat laporan keuangan yang tercatat secara komputerisasi tanpa adanya lagi kesalahan pencatatan yang tanpa disadari.

Pelatihan ini mendapat dukungan yang baik dari pihak peserta SDM pengelola keuangan pesantren sehingga pelatihan dapat dilaksanakan dengan lancar. Pemberian materi pada sesi 1 disampaikan dengan metode ceramah yang kemudian dilanjutkan dengan sesi tanya jawab. Sedangkan untuk materi pada sesi 2 disampaikan dengan metode praktik. Pada sesi 2 ini para peserta diberikan contohcontoh transaksi dan dilatih untuk

Tabel 1. Hasil Kuesioner Peserta Pelatihan mengenai Pemahaman Laporan

Keuangan

\begin{tabular}{|c|c|c|c|c|c|c|c|c|c|c|c|c|}
\hline \multirow{3}{*}{ No } & \multirow{3}{*}{ Pernyataan } & \multicolumn{10}{|c|}{ Jawaban } & \multirow{3}{*}{ Mean } \\
\hline & & \multicolumn{2}{|c|}{ SS } & \multicolumn{2}{|c|}{$\mathbf{S}$} & \multicolumn{2}{|c|}{ RG } & \multicolumn{2}{|c|}{ TS } & \multicolumn{2}{|c|}{ STS } & \\
\hline & & $\mathrm{Fr}$ & $\%$ & $\mathrm{Fr}$ & $\%$ & $\mathrm{Fr}$ & $\%$ & $\mathrm{Fr}$ & $\%$ & $\mathrm{Fr}$ & $\%$ & \\
\hline 1. & $\begin{array}{lr}\text { Setelah } & \text { mengikuti } \\
\text { pelatihan } & \text { tentang } \\
\text { pelaporan } & \text { keuangan, } \\
\text { saya memahami prinsip } \\
\text { untuk penyusunan } \\
\text { laporan keuangan }\end{array}$ & 2 & 16.7 & 9 & 75 & 1 & 8.3 & & & & & 4.08 \\
\hline
\end{tabular}

pencatatan keuangan hingga menjadi laporan keuangan melalui aplikasi.

Dimulai dari sesi 1 sampai sesi ke-2 narasumber pun berusaha untuk melakukan engagement dengan peserta sehingga peserta dapat dengan aktif berpartisipasi dan tertarik dengan pelatihan yang diberikan.

Kegiatan ini merupakan kegiatan pengabdian masyarakat yang rutin dilakukan dilingkungan Universitas Negeri Jakarta sebagai salah satu dari pelaksanaan Tri Dharma Perguruan Tinggi. Pihakpihak yang terkait dalam hal ini adalah Universitas Negeri Jakarta selaku pemberi pelatihan, dan SDM pengelola keuangan pondok pesantren Qotrun Nada Depok Jawa Barat sebagai peserta pelatihan.

Dari lembar evaluasi hasil kuesioner mengenai evaluasi pelaksanaan pelatihan menurut Paramita (2016) diterima oleh panitia diperoleh umpan balik dari para peserta pelatihan. Berdasarkan lembar eveluasi tersebut peserta menyampaikan apresiasinya dan merasakan manfaat yang cukup besar setelah mengikuti pelatihan. Berikut hasil kuesioner para peserta pelatihan: 


\begin{tabular}{|c|c|c|c|c|c|c|c|c|c|c|c|c|}
\hline \multirow{3}{*}{ No } & \multirow{3}{*}{ Pernyataan } & \multicolumn{9}{|c|}{ Jawaban } & & \multirow{3}{*}{ Mean } \\
\hline & & \multicolumn{2}{|c|}{ SS } & \multicolumn{2}{|c|}{$\mathbf{S}$} & \multicolumn{2}{|c|}{ RG } & \multicolumn{2}{|c|}{ TS } & \multicolumn{2}{|c|}{ STS } & \\
\hline & & $\mathrm{Fr}$ & $\%$ & & $\%$ & Fr & $\%$ & Fr & $\%$ & $\mathrm{Fr}$ & $\%$ & \\
\hline 2. & $\begin{array}{lr}\text { Setelah } & \text { mengikuti } \\
\text { pelatihan } & \text { tentang } \\
\text { pelaporan } & \text { keuangan, } \\
\text { saya } & \text { memiliki } \\
\text { peningkatan ide/ } \text { konsep } \\
\text { untuk } & \text { menghindari } \\
\text { kesalahan } & \text { dalam } \\
\text { pencatatan } & \end{array}$ & 4 & 33. & 7 & 58.3 & 1 & 8.3 & & & & & 4.25 \\
\hline 3. & $\begin{array}{lr}\text { Setelah } & \text { mengikuti } \\
\text { pelatihan } & \text { tentang } \\
\text { pelaporan } & \text { keuangan, } \\
\text { saya memahami prinsip } \\
\text { akuntansi } \\
\text { mewujudkan } \\
\text { transparansi } \\
\text { akuntanbilitas }\end{array}$ & 1 & 8.3 & s & 75 & 3 & 16.7 & & & & & 3.92 \\
\hline 4. & $\begin{array}{lr}\text { Setelah } & \text { mengikuti } \\
\text { pelatihan } & \text { tentang } \\
\text { pelaporan } & \text { keuangan, } \\
\text { saya } & \text { memiliki } \\
\text { peningkatan ide/ } & \text { konsep } \\
\text { untuk mewujudkan } \\
\text { tranparansi r dan } \\
\text { akuntanbilitas }\end{array}$ & 1 & 8.3 & S & 75 & 2 & 16.7 & & & & & 3.92 \\
\hline 5. & $\begin{array}{lr}\text { Setelah } & \text { mengikuti } \\
\text { pelatihan } & \text { tentang } \\
\text { pelaporan } & \text { keuangan, } \\
\text { saya } & \text { memiliki } \\
\text { pemahaman } & \text { tentang } \\
\text { teknik-teknik } & \\
\text { penyusunan } & \text { laporan } \\
\text { keuangan } & \\
\end{array}$ & 3 & 25 & 7 & 58.3 & 2 & 16.7 & & & & & 4.08 \\
\hline 6. & $\begin{array}{lr}\text { Setelah } & \text { mengikuti } \\
\text { pelatihan } & \text { tentang } \\
\text { pelaporan } & \text { keuangan, } \\
\text { saya } & \text { memiliki } \\
\text { pemahaman } & \text { tentang } \\
\text { cara } & \text { mencegah } \\
\text { timbulnya } & \text { kesalahan } \\
\text { pencatatan } & \end{array}$ & 3 & 25 & 7 & \begin{tabular}{|l|l}
58.3 \\
\end{tabular} & 1 & 8.3 & & & & & 3.83 \\
\hline 7. & $\begin{array}{lr}\text { Setelah } & \text { mengikuti } \\
\text { pelatihan } & \text { tentang } \\
\text { pelaporan } & \text { keuangan, } \\
\text { saya lebih } & \text { memahami } \\
\text { prosedur } & \text { dalam } \\
\text { menyelesaikan } & \text { laporan } \\
\text { keuangan, } & \text { sehingga }\end{array}$ & 2 & 16. & 7 & 58.3 & 1 & 8.3 & & & & & 3.42 \\
\hline
\end{tabular}


Etty Gurendrawati ${ }^{1}$, Yunika Murdayanti ${ }^{2}$ dan Susi Indriani ${ }^{3}$ Aksiologiya: Jurnal Pengabdian Kepada Masyarakat. Vol.4, No.1, Februari 2020 Hal 20 - 36

\begin{tabular}{|c|c|c|c|c|c|c|c|c|c|c|c|c|}
\hline \multirow{3}{*}{ No } & \multirow{3}{*}{ Pernyataan } & \multicolumn{10}{|c|}{ Jawaban } & \multirow{3}{*}{ Mean } \\
\hline & & \multicolumn{2}{|c|}{ SS } & \multicolumn{2}{|c|}{$\mathbf{S}$} & \multicolumn{2}{|c|}{ RG } & \multicolumn{2}{|c|}{ TS } & \multicolumn{2}{|c|}{ STS } & \\
\hline & & $\overline{\mathrm{Fr}}$ & $\%$ & $\mathrm{Fr}$ & $\%$ & $\mathrm{Fr}$ & $\%$ & $\mathrm{Fr}$ & $\%$ & Fr & $\%$ & \\
\hline & $\begin{array}{l}\text { terhindar dari kesalahan } \\
\text { pencatatan }\end{array}$ & & & & & & & & & & & \\
\hline 8. & $\begin{array}{lr}\text { Setelah } & \text { mengikuti } \\
\text { pelatihan } & \text { tentang } \\
\text { pelaporan } & \text { keuangan, } \\
\text { saya } & \text { memiliki } \\
\text { keterampilan } & \\
\text { pencatatan } & \text { keuangan } \\
\text { sesuai dengan } & \text { standar } \\
\text { akuntansi keuangan }\end{array}$ & & & 10 & 83.3 & 1 & 8.3 & & & 1 & 8.3 & 3.67 \\
\hline 9. & $\begin{array}{lr}\text { Setelah } & \text { mengikuti } \\
\text { pelatihan } & \text { tentang } \\
\text { pelaporan } & \text { keuangan, } \\
\text { saya } & \text { memiliki } \\
\text { keterampilan } & \text { untuk } \\
\text { mengatasi } & \text { kesalahan } \\
\text { membuat jurnal }\end{array}$ & & & 7 & 58.3 & 4 & 33.3 & & & 1 & 8.3 & 3.42 \\
\hline 10. & $\begin{array}{lr}\text { Setelah } & \text { mengikuti } \\
\text { pelatihan } & \text { tentang } \\
\text { pelaporan } & \text { keuangan, } \\
\text { saya } & \text { memiliki } \\
\text { keterampilan } & \text { untuk } \\
\text { membuat } & \text { laporan } \\
\text { keuangan } & \end{array}$ & 2 & 16.7 & 7 & 58.3 & 2 & 16.7 & 1 & 8.3 & & & 3.83 \\
\hline 11. & 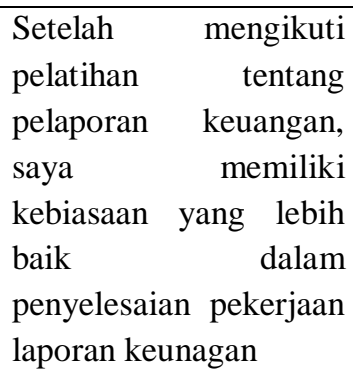 & 4 & 33.3 & 7 & 58.3 & & & & & & & 4 \\
\hline 12. & $\begin{array}{lr}\text { Setelah } & \text { mengikuti } \\
\text { pelatihan } & \text { tentang } \\
\text { pelaporan } & \text { keuangan, } \\
\text { saya } & \text { mengalami } \\
\text { perubahan } & \text { sikap untuk } \\
\text { menghindari } & \text { kesalahan } \\
\text { menjurnal } & \text { laporan } \\
\text { keuangan } & \\
\end{array}$ & 3 & 25 & 6 & 50 & 3 & 25 & & & & & 4 \\
\hline 13. & $\begin{array}{lr}\text { Setelah } & \text { mengikuti } \\
\text { pelatihan } & \text { tentang } \\
\text { pelaporan } & \text { keuangan, } \\
\text { saya memiliki dorongan } \\
\text { dari diri sendiri untuk } \\
\text { menghindari kesalahan }\end{array}$ & 1 & 8.3 & 8 & 66.7 & 3 & 25 & & & & & 3.83 \\
\hline
\end{tabular}




\begin{tabular}{|c|c|c|c|c|c|c|c|c|c|c|c|c|}
\hline \multirow{3}{*}{ No } & \multirow{3}{*}{ Pernyataan } & \multicolumn{10}{|c|}{ Jawaban } & \multirow{3}{*}{ Mean } \\
\hline & & \multicolumn{2}{|c|}{ SS } & \multicolumn{2}{|c|}{$\mathbf{S}$} & \multicolumn{2}{|c|}{ RG } & \multicolumn{2}{|c|}{ TS } & \multicolumn{2}{|c|}{ STS } & \\
\hline & & $\mathrm{Fr}$ & $\%$ & Fr & $\%$ & $\mathrm{Fr}$ & $\%$ & $\mathrm{Fr}$ & $\%$ & $\mathrm{Fr}$ & $\%$ & \\
\hline & $\begin{array}{ll}\text { menjurnal laporan } \\
\text { keuangan }\end{array}$ & & & & & & & & & & & \\
\hline 14. & $\begin{array}{lr}\text { Materi } & \text { pelatihan } \\
\text { tentang } & \text { pelaporan } \\
\text { keuangan } & \text { berguna } \\
\text { dalam } & \text { proses } \\
\text { menyelesaikan } & \\
\text { pekerjaan keuangan. }\end{array}$ & 4 & 33.3 & 8 & 66.7 & & & & & & & 4.33 \\
\hline 15. & $\begin{array}{lr}\text { Fasilitas } & \text { pelatihan } \\
\text { tentang pelaporan } \\
\text { keuangan memadai } \\
\text { (misalnya: ruangan, } \\
\text { tampilan materi, buku, } \\
\text { dll) }\end{array}$ & 6 & 50 & 5 & 41.7 & 1 & 8.3 & & & & & 4.42 \\
\hline 16. & $\begin{array}{lr}\text { Instruktur pelatihan } \\
\text { mempu menyampaikan } \\
\text { materi pelatihan tentang } \\
\text { pelaporan keuangan } \\
\text { dengan baik }\end{array}$ & 6 & 50 & 6 & 50 & & & & & & & 4.50 \\
\hline 17. & $\begin{array}{l}\text { Metode penyampaian } \\
\text { materi pelatihan mampu } \\
\text { menyampaikan materi } \\
\text { pelatihan dengan baik. }\end{array}$ & 7 & 58.3 & 5 & 41.7 & & & & & & & 4.58 \\
\hline 18. & $\begin{array}{lr}\text { Setelah } & \text { mengikuti } \\
\text { pelatihan } & \text { tentang } \\
\text { pelaporan } & \text { keuangan, } \\
\text { saya } & \text { memiliki } \\
\text { peningkatan } & \text { keinginan } \\
\text { untuk } & \text { belajar } \\
\text { (mempelajari } & \text { lebih } \\
\text { lanjut) mengenai upaya } \\
\text { mencegah } & \text { kesalhan } \\
\text { pencatatan. } & \end{array}$ & 1 & 8.3 & 11 & 91.7 & & & & & & & 4.08 \\
\hline 19. & $\begin{array}{lr}\text { Setelah } & \text { mengikuti } \\
\text { pelatihan } & \text { tentang } \\
\text { pelaporan } & \text { keuangan, } \\
\text { saya } & \text { memilki } \\
\text { peningkatan } & \text { keinginan } \\
\text { untuk } & \text { belajar } \\
\text { (mempelajari } & \text { lebih } \\
\text { lanjut) } & \text { mengenai } \\
\text { prosedur } & \text { melaporkan } \\
\text { keuangan sesuai dengan } \\
\text { prinsip akuntansi yang } \\
\text { berlaku }\end{array}$ & 3 & 25 & 8 & 66.7 & 1 & 25 & & & & & 4.17 \\
\hline 20. & $\begin{array}{lr}\begin{array}{l}\text { Setelah } \\
\text { pelatihan }\end{array} & \text { mengikuti } \\
\text { tentang }\end{array}$ & 3 & 25 & 9 & 75 & & & & & & & 4.25 \\
\hline
\end{tabular}


Etty Gurendrawati ${ }^{1}$, Yunika Murdayanti ${ }^{2}$ dan Susi Indriani ${ }^{3}$ /Aksiologiya: Jurnal Pengabdian Kepada Masyarakat. Vol.4, No.1, Februari 2020 Hal 20 - 36

\begin{tabular}{|c|c|c|c|c|c|c|c|c|c|c|c|c|}
\hline \multirow{3}{*}{ No } & \multirow{3}{*}{ Pernyataan } & \multicolumn{10}{|c|}{ Jawaban } & \multirow{3}{*}{ Mean } \\
\hline & & \multicolumn{2}{|c|}{ SS } & \multicolumn{2}{|c|}{$\mathbf{S}$} & \multicolumn{2}{|c|}{ RG } & \multicolumn{2}{|c|}{ TS } & \multicolumn{2}{|c|}{ STS } & \\
\hline & & $\mathrm{Fr}$ & $\%$ & $\mathrm{Fr}$ & $\%$ & $\mathrm{Fr}$ & $\%$ & $\mathrm{Fr}$ & $\%$ & $\mathrm{Fr}$ & $\%$ & \\
\hline & $\begin{array}{l}\text { pelaporan keuangan, } \\
\text { saya memiliki } \\
\text { keinginan untuk } \\
\text { menyelesaikan } \\
\text { pekerjaan keuangan } \\
\text { secara baik/ tidak } \\
\text { terjadi kesalahan. }\end{array}$ & & & & & & & & & & & \\
\hline 21. & $\begin{array}{lr}\text { Setelah } & \text { mengikuti } \\
\text { pelatihan } & \text { tentang } \\
\text { pelaporan } & \text { keuangan, } \\
\text { saya memilki keinginan } \\
\text { untuk menyelesaikan } \\
\text { laporan } & \text { keuangan } \\
\text { secara baik } & \end{array}$ & 7 & 58.3 & 5 & 41.7 & & & & & & & 4.58 \\
\hline
\end{tabular}

Berdasarkan hasil kuesioner diatas diketahui bahwa peserta sangat setuju dan sangat antusias bahwa setelah mengikuti pelatihan tentang pelaporan keuangan, para peserta memilki keinginan untuk menyelesaikan laporan keuangan secara baik. Hal tersebut ditunjukkan dengan hasil rata-rata jawaban peserta yang memiliki hasil tertinggi. Dari hasil evaluasi tersebut diperoleh bahwa peserta mendapatkan tambahan pengetahuan mengenai pengelolaan keuangan pesantren yang baik, mereka juga merasa tertarik dengan praktik menggunakan aplikasi yang diberikan oleh panitia.

Begitu pula umpan balik yang disampaikan mengenai narasumber juga positif, peserta berpendapat bahwa narasumber menguasai materi dan dapat menyampaikan materi dengan jelas dan menarik terbukti dari hasil pernyataan tertinggi dengan jawaban rata-rata sangat setuju yaitu metode penyampaian materi pelatihan mampu menyampaikan materi pelatihan dengan baik. Selama proses pelatihan berlangsung para peserta menunjukan antusisme yang sangat baik, yang ditunjukan dengan banyak peserta pelatihan yang berpartisipasi di sesi tanya jawab, dan aktifnya diskusi yang berlangsung selama tanya jawab tersebut. Peserta menyampaikan agar pelatihan serupa dapat dilaksanakan kembali.

Namun demikian, tim pengabdian masyarakat menghadapi kendala bahwa pelaporan keuangan yang sudah terstandarisasi dan diterbitkan oleh Ikatan Akuntan Indonesia bekerjasama dengan Bank Indonesia belum sepenuhnya bisa diterapkan di pondok pesantren karena karakteristik yang pesantren miliki bahwa seluruhnya masih berdasarkan pada keputusan teratas yaitu Kyai sebagai pimpinan pesantren dan tantangan kedua adalah tidak mudah menerapkan konsep laporan keuangan karena para SDM pengelola laporan keuangan di pesantren tidak memiliki background 
pendidikan keuangan sehingga

penguasaan materi lebih kepada

pencatatan penerimaan dan

pengeluaran keuangan saja atau

laporan operasional pesantren.

\section{SIMPULAN}

Pengelolaan keuangan sangat penting untuk dilakukan, karena dengan pengelolaan keuangan yang baik maka suatu institusi juga akan mendapatkan keberlangsungan operasional jangka panjang dengan pirnsip akuntabilitas yang baik. Para peserta pelatihan atau SDM pengelola keuangan merupakan pihak yang penting untuk diberi pengetahuan mengenai pengelolaan keuangan pesantren yang berlandaskan yayasan, selain terdapat pertanggungjawaban keuangan melalui adanya pelaporan keuangan yang baik.

Tingkat ketercapaian kegiatan pelatihan ini sulit dibuktikan dengan angka namun pencapaian ini terlihat melalui bukti adanya penambahan pengetahuan tentang pengelolaan keuangan pesantren yang benar dan antusiasnya peserta dalam memahami pembuatan laporan keuangan yang baik, yang sekaligus merupakan indikasi dari adanya peningkatan pemahaman dan pengetahuan keuangan. Hasil dari pelatihan ini bahwa dibutuhkan kegiatan pengabdian masyarakat lanjutan yaitu untuk memantau hasil yang sudah berjalan termasuk mengembangkan kegiatan yang sudah ada sangat diperlukan serta kerjasama yang mengikat antara institusi pendidikan perguruan tinggi dan pondok pesantren untuk keberlangsungan dan tercapainya tujuan akhir pengabdian masyarakat ini.

Berdasarkan hasil kuesioner diatas diketahui bahwa peserta sangat setuju dan sangat antusias bahwa setelah mengikuti pelatihan tentang pelaporan keuangan, para peserta memilki keinginan untuk menyelesaikan laporan keuangan secara baik. Hal tersebut ditunjukkan dengan hasil rata-rata jawaban peserta yang memiliki hasil tertinggi. Dari hasil evaluasi tersebut diperoleh bahwa peserta mendapatkan tambahan pengetahuan mengenai pengelolaan keuangan pesantren yang baik, mereka juga merasa tertarik dengan praktik menggunakan aplikasi yang diberikan oleh panitia.

Begitu pula umpan balik yang disampaikan mengenai narasumber juga positif, peserta berpendapat bahwa narasumber menguasai materi dan dapat menyampaikan materi dengan jelas dan menarik terbukti dari hasil pernyataan tertinggi dengan jawaban rata-rata sangat setuju yaitu metode penyampaian materi pelatihan mampu menyampaikan materi pelatihan dengan baik. Selama proses pelatihan berlangsung para peserta menunjukan antusisme yang sangat baik, yang ditunjukan dengan banyak peserta pelatihan yang berpartisipasi di sesi tanya jawab, dan aktifnya diskusi yang berlangsung selama tanya jawab tersebut. Peserta menyampaikan agar pelatihan serupa dapat dilaksanakan kembali.

Namun demikian, tim pengabdian masyarakat menghadapi 
kendala bahwa pelaporan keuangan yang sudah terstandarisasi dan diterbitkan oleh Ikatan Akuntan Indonesia bekerjasama dengan Bank Indonesia belum sepenuhnya bisa diterapkan di pondok pesantren karena karakteristik yang pesantren miliki bahwa seluruhnya masih berdasarkan pada keputusan teratas yaitu Kyai sebagai pimpinan pesantren dan tantangan kedua adalah tidak mudah menerapkan konsep laporan keuangan karena para SDM pengelola laporan keuangan di pesantren tidak memiliki background pendidikan keuangan sehingga penguasaan materi lebih kepada pencatatan penerimaan dan pengeluaran keuangan saja atau laporan operasional pesantren.

\section{DAFTAR PUSTAKA}

Anwar, Kasful. 2010. Kepemimpinan Kiai Pesantren: Studi terhadap Pondok Pesantren di Kota Jambi. Konstekstualita. Volume 25 No. 2. Hal. 225-254

Arifin, Zainal dan Ikhsan Budi Riharjo. 2013. Pertanggungjawaban Keuangan Pondok Pesantren : Studi pada Yayasan Nazhatut Thullab. Jurnal Ilmu \& Riset Akuntansi. Vol. 3. No.11.Hal.1-13

Fess, Reeve, Warren. 2009. PengantarAkuntansi dan Bisnis Edisi ke-21. United South Western: Thomson.

Fitri, Afriliana. 2014. Pengelolaan Dana Bantuan Operasional Sekolah (BOS) Sekolah Dasar Negeri Kecamatan Mandiangin Koto Selayan Kota Bukit Tinggi. Jurnal Administrasi
Pendidikan. Volume 2 Nomor 1, Hal. 33-39.

Kieso, Weygandt, Warfield. 2010. Intermediate Accounting Volume 1 dan 2 IFRS Edition. United States: University of California, Santa Barbara.

Paramita, Ayu Candra Dian Paramita. Fridayana Yudiaatmaja, dan I Wayan Bagia. 2016. Evaluasi Pelaksanaan Pelatihan Pembuatan Kerajinan Tangan. e-Journal Bisma Universitas Pendidikan Ganesha. Vol. 4. Hal. 1-12.

Robins, Stephen P dan Mary Coulter. 2010. Manajemen. Jilid 1 dan 2. Edisi Kesepuluh. Jakarta : Erlangga.

Subkhan. 2012. Peranan Kyai Dalam Manajemen Pembiayaan Pendidikan Di Pondok Pesantren Asma' Chusna Kranji Kedungwuni Kabupaten Pekalongan. Journal of Economic Education. Volume 1 Nomor 1. Hal. 79-83

Suyono. 2013. Komputer Akuntansi Kelas IX Jilid I. Jakarta: Kementerian Pendidikan dan Kebudayaan Republik Indonesia

Usman, Idris Muhammad. 2013. Pesantren sebagai Lembaga Pendidikan Islam. Jurnal Al Hikmah. Volume XIV no. 1.Hal. 101-119

Yakin, Nurul. 2014. Studi Kasus Pola Manajemen Pondok Pesantren Al-Raisiyah di Kota Mataram. Ulumuna Jurnal Studi Keislaman, Volume 18 Nomor 1. Hal.199-220 